\title{
O MÉTODO ISOTÓPICO Re-Os: CARACTERÍsTICAS E POTENCIALIDADES
}

\section{Ciro Teixeira Correia}

Embora as primeiras referências a respeito das possibilidades de utilização do sistema isotópico Re-Os (Rênio-Ósmio) para fins geocronológicos remonte aos anos 50, apenas a partir dos anos 80 se aprofundou $e$ difundiu o conhecimento das particularidades geoquímicas e do enorme potencial que este sistema apresenta para os estudos relacionados aos processos de evolução da litosfera terrestre; de fusão parcial e de diferenciação do manto da terra; de diferenciaçăo magmática por cristalização fracionada; e para estudos de grande importância económica relacionados à determinaçà̃o das fontes dos metais e do tempo de colocaçầ de mineralizaçổes em jazidas de minério.

O método baseia-se no decaimento beta $(-b)$ do 187 Re para o 187 Os segundo a constante de decaimento (I) de $1.64 \pm 0.005 \times 10-11 \times$ anos-1 (Lindner et al., 1989), apresentando o 187 Re a meia vida de 42,6 bilhôes de anos. Muito do seu potencial encontra-se relacionado a particularidades geoquímicas dos elementos químicos $\mathrm{Re}$ e Os. Enquanto o Re se comporta como elemento incompativel durante os processos de fusẫo parcial do manto e da crosta, o Os é retido na olivina, nos sulfetos e em ligas metálicas refratírias dos resíduos mantélicos. Desta forma, o Os encontra-se drasticamente empobrecido nas rochas crustais enquanto o Re se encontra profundamente enriquecido. Como conseqüência os reservatórios crustais apresentam razôes Re/Os dramaticamente diferentes e, em função do tempo, composiçōes isotópicas muito distintas com contrastes que nảo sâo observados em nenhum outro sistema isotópico quando se comparam diferenças entre reservatórios crustais e os mantélicos (razōes 187Re/188Os e 187Os/188Os, $\mathrm{cm}$ condritos e no manto superior, equivalentes respectivamente a 0,40 e 0,1271 , enquanto na crosta superior esses valores passam à 42 e 1,69, segundo Walker; Morgan, 1989 e, Snow; Reisberg, 1995).

Além disto os elementos $\mathrm{Re}$ e Os, ao contrário dos demais sistemas isotópicos atualmente mais utilizados em geocronologia (K-Ar, Ar-Ar, Rb-Sr, Sm-Nd e U-Pb), são elementos fortemente caleófilos, concentrando-se preferencialmente nas fases sulfetadas em relaçăo ds silicáticas, permitindo assim se estudar diretamente os minérios de um determinado jazimento e não o fazế-lo por vias indiretas, através da aplicaçâo de outros métodos isotópicos nas fases silicáticas hospedeiras. Considerando-se adicionalmente que o Os é um dos elementos do grupo da Platina, pode-se deduzir a importância que este método representa no estudo da derivação de metais preciosos em fluidos magmáticos mineralizantes e nos processos de fracionamento normalmente associados à concentração dos elementos do grupo da platina nos complexos estratiformes, que têm se constituido como fonte primária por excelência para prospeç̧ão e exploraçào destes metais.

Uma das limitaçōes que retardaram a difusão do método Re-Os encontra-se associada ao fato de que Os é um dos elementos menos abundantes na natureza. Sua concentração varia entre valores de algumas picogramas por grama ( $\mathrm{pg} / \mathrm{g}$, ou seja, algumas partes por trilhão de partes: ppt)) na maioria das rochas crustais e concentrações da ordem de 1 micrograma por grama (mg/g) nos sulfetos ou até $50 \mathrm{mg} /$ $\mathrm{g}$ em meteoritos sideríticos (Völkening et al, 1991). Este fato implica na necessidade de métodos analiticos extremamente sensíveis e precisos para a determinação da concentração desse elemento $\mathrm{e}$ de seus isótopos. Além disso, em funçào do isótopo radiogênico do Os (187Os) apresentar o mesmo número de massa do isótopo que lhe dá origem $(187 \mathrm{Re})$, torna-se necessário separá-los da amostra a ser estudada antes de se proceder a sua extração e análise final. Deve-se considerar também que o método químico para extração de Os é extremamente delicado e complicado (Shirey; Walker, 1995) e que se necessita de laboratórios "limpos", dentro de padrōes internacionais, e reagentes ultra-puros, para se evitar eventuais contaminaçōes durante os procedimentos de extração e análise.

Essas análises só se tornaram viáveis com o desenvolvimento de equipamentos para espectrometria de massa por ionização térmica negativa (NTI-MS), uma vez que medidas precisas pela via tradicional de ionização térmica positiva não se aplicavam, dentro dos limites de precisào desejados, para os isótopos de Os em funçâo do extremamente elevado potencial de ionização deste elemento. Pela nova técnica (NTIMS) passou a ser possivel analisar com precisôes menores que $0,01 \%$, razôes isotópicas de Os em amostras que continham este elemento químico em quantidades da ordem de alguns nanogramas por grama de amostra (algumas ppt). Como conseqüència, uma vez superados os problemas analíticos, este método vềm se difundindo grandemente nos melhores centros de pesquisa ligados as geociências em âmbito mundial, permitindo avanços significativos na compreensào dos importantes problemas geológicos e metalogenéticos que careciam até então de uma ferramenta de trabalho adequada para sua resolução.

Referéncias Bibliográficas

LINDNER, M; LEITCH D.A.; RUSS G.P.; BASAN, J.M. AND BORG, R.J., 1989, Direct detemination of the half-life of 187Re. Geochim. Cosmochim. Acta, 53:1597-606.

SHIREY, S.B. \& WALKER, R.J..1995, Carius tube digestion for low-blank rhenium-osmium analysis. Submitted to Analytical Chemistry, American Chemical society.

SNOW, J.E. \& REISBERG L., 1995, Os isotopic systematics of the MORB mantle: results from altered abyssal peridotites. Earth and Planetary Science Letters, 133:411-21.

VOLKENING, J; WALCZYK, T. AND HEUMANN, K.G., 1991, Osmium isotope ratio determinations by negative thermal ionization mass spectrometry. Int. J. Mass. Spect. Ion Process, 105:147-59.

WALKER, R.J. AND MORGAN, J.W., 1989, Rhenium-osmium systematics of carbonaceous chondrites. Science, 243:519-22. 